\title{
Implementation of Thoharoh in early childhood through Telling Story in Babadan Village
}

\author{
Lilis Rahmawati \\ STAI Miftahul Ula Nganjuk \\ elrahmawati22@gmail.com
}

Article History:

Received: Oct $12^{\text {th, }} 2019$

Revised: Feb $13^{\text {th, }} 2020$

Accepted: March 30th, 2020

\begin{abstract}
Thoharoh became the basis of a practice of worship, as it became the condition of worship. So it is necessary to be taught since early childhood is good and correct. Since early childhood is the Golden Age. This research aims to discuss the implementation of education in Thoharoh in early childhood in Babadan village. Using a descriptive method is a clear picture of delivering, presenting, and concluding data. Population retrieval and samples from the research object as a tool to obtain data from an issue that is also required by the authors. As for digging data, the methods used are documentation methods, interviews, polls and to know the type of data using qualitative data. His study was done very impressively through various fun games, demonstrations and Thoharoh festivals. The results showed that Thoharoh could be implemented early on through a pleasant method. With the hope that parents participate in this religious education so that the child can practice it optimally.
\end{abstract}

Keyword: Thoharoh, early childhood, Babadan

\section{INTRODUCTION}

Childhood is one of the most important times in human life. Because it is a foothold of the next phases in the process of growth and education process as well as personal coaching of a child(Bjorklund \& Pellegrini, 2000). At this time the child absorbs many things, planting basic principles, values and tendencies will shape human behavior in the future while already a mature man(Vygotsky \& Vygotsky, 2006).

Bloom's research on Wiyani (Wiyani, 2014) suggests that intellectual development is very rapidly occurring in early childhood, about $50 \%$ of intelligence development is at 4 years old, $30 \%$ next at 8 years old, and the remaining $20 \%$ occurs in the middle of the end of the second Decade. Therefore, we must maximize the early age so that the children can develop optimally. 
Maria Montessori in with said that in early childhood children were at the Golden Age(Lillard, 2013; Schorn, 1952; Shampo \& Kyle, 1976). This period is a sensitive period of children, where the child quickly and easily receives the stimulus from its environment. Montessori also reveals the age of gold is the age when the child is sensitive to receiving stimulation and education efforts from adults and the environment is either intentional or no(Lillard, 2012, 2013; "MONTESSORI," 1952; Stendler, 1965)t. In these times of sensitivity, there is the maturation of physical and psychic functions so that the child is ready to respond and make the task of the development expected to appear in the pattern of everyday behavior(Sujiono, 2009).

In the childhood of this child is very important we have planted education, not only general education but also religious education("Encyclopedia of bilingualism and bilingual education," 1998; Hobson, 2014; Ketut Sudarsana, 2017; Zhang, 2014). The practice of compulsory worship must be introduced because this will be attached to the child and brought by the child to adulthood. In the Islamic religion, all practices or practice of worship always begins with the sanctity (cleanliness) even before we face to carry out obligations, a compulsory Muslim net from the small impurity and large impurity.

For the hadeeth is:

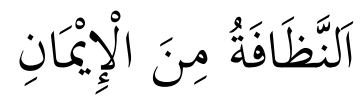

"The cleanliness of some faith"

The phrase above encourages us to keep clean, Islam is very concerned about cleanliness, both physical hygiene and spiritual hygiene. Before praying to Allah SWT we are obliged in a state of holy and Clean, both holy from clothing, where even ourselves also must be in a holy and clean state, this is called Thoharoh (Ahmad, 2014; Khobir, 2013).

For a Muslim, Thoharoh is highly recommended because it is one of the conditions of worship. Studying Thoharoh The law is mandatory because if you do not know about the ordinance Thoharoh, there are many practices of worship such as prayers that eventually become invalid because of the wrong Thoharoh.

In practice a day many people underestimate Thoharoh and he thinks it is not important, not even a few people forget about the ordinance Thoharoh because they went through the learning Thoharoh just so. Learning about Thoharoh is not a new thing. Thoharoh already taught at the level of Raudhotul Athfal (RA), Kindergarten (TK), on the subject of Islamic religious Education (PAI) in Elementary School (SD), in Madrasah Ibtidaiyah (MI), Madrasah Diniyah (Madin) and the educational Park Al-Qur'an. This is because the learning of Thoharoh is taught with the material without practice and delivered to the child without the 
impression, so the child is negligent. Early childhood children have unique characteristics and their world is the world to play so that the submission of learning must be adapted to their world. The support of teachers and parents is also needed so that children can practice Thoharoh on daily life correctly so that all the practice of worship is correct according to Islamic law.

Babadan Village is one of the villages in the district of Patianrowo Nganjuk. It has several institutions such as KINDERGARTEN, RA, SD, MI, Madin, and TPQ that teach you the sacred habit. But in practice, a lot of mistakes occur. This was seen when it was held several times in the sacred practice of Madrasah Diniyah Baitul Muttaqin (Madin), there were many mistakes in practice. From 135 students, the practice of ablution 90 more of them have errors in the Ablution, among them is not by the Ablution pillars, until the cleanliness in Thoharoh.

Back to the problems that researchers have exposed above, that's why it was what made the researcher research the title "Learning Thoharoh in early childhood in Babadan village".

The problem formulation of this research is how is the application of Thoharoh education in early childhood in Babadan village? While the purpose of this research is to describe the establishment of Thoharoh in early childhood in Babadan village.

\section{LITERATURE REVIEW}

\section{Early childhood}

Early childhood is an individual who is experiencing a rapid and fundamental development process for the next life. Early childhood was in the range of 0-8 years, at this time the process of growth and development in various aspects is experiencing a rapid time in the development of human life.

Based on Law No. 20 of 2003 on the national education system relating to early childhood Education Article 28 paragraph 1 states "Early childhood education is held for children from birth to six years and is not a prerequisite for following basic education"(Soebahar, 2013).

In Developmentally Appropriate Practices (DAP), it is stated that early childhood is a child who is vulnerable to age $0-8$ years. In this phase, the child has very rapid physical and mental development. DAP is one of the references in the development of early childhood education published by the Early Childhood Education Association in the United States(CARTA, 1994)

\section{Early childhood characteristics}

Early childhood children have different characteristics with adults, they are 1) unique, meaning they have different abilities, 2) egocentric, 3) active and energetic 4) exploratory and adventurous 5) relatively spontaneous 6) easy frustration 7) Less consideration in doing something, 8) low attention, they can only focus on 
something in the short duration. 9) Children are passionate to learn and learn a lot from experience(Anderson et al., 2003; Ashiabi, 2007; Salsberry \& Reagan, 2005; Tremblay et al., 2004; Zelazo et al., 2003).

Early childhood is also very plain and likes to emulate, so when we teach something we ought to teach with a practice that can be seen to be exempted. The world of early childhood is the world of the play, and the world is happy, so the way we teach it must also be exciting(Australian Institute for Teaching and School Leadership et al., 2011; Dyson et al., 2018; Schachter et al., 2016; Stipek \& Byler, 2004).

\section{Early childhood theories}

Tabularasa's theory, which states that the child is like a white paper, everything that is taught will be received by the child. This is very important, so that educators, not arbitrarily give their curiosity. Because they will record and repeat what they receive(Needham \& Libertus, 2008; Ramscar \& Gitcho, 2007).

The maturational theory states that the child will grow to the fullest when placed in an optimal environment. Children are like planted seeds, which are to be treated, given water fertilizers, getting enough sunlight and an ideal climate to thrive(P. M. Crittenden, 2005; P. M. K. Crittenden \& Dallos, 2009; Harmon, 1967; Winnicott, 2018).

Nativism theory says that families are an important factor in child growth. Therefore children must also obtain guidance and support from the child(Newcombe, 2011, 2013).

\section{Thoharoh}

In terms of language, the word al Tahaarah is derived from Lafadz Thahara, YathHuru, Thuhran, Thaharatan that also has a sacred meaning, cleanse and purify. In terms of terminology, the word Al Tahaarah is intended as an activity to remove the impurity and also unclean.

For the chaste of the Hadats, ablution is the most frequently performed sacred activity. Ablution itself is an activity of washing with certain water parts of the body when a Muslim will perform worship to Allah SWT. Certain portions of the body to be washed were ordained by God as in Sura Al-Maidah verse 6 .

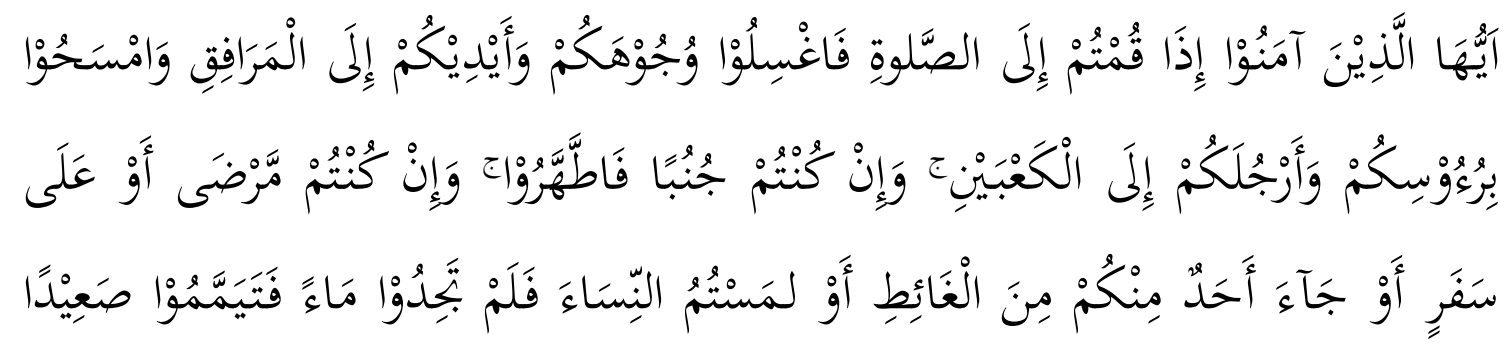




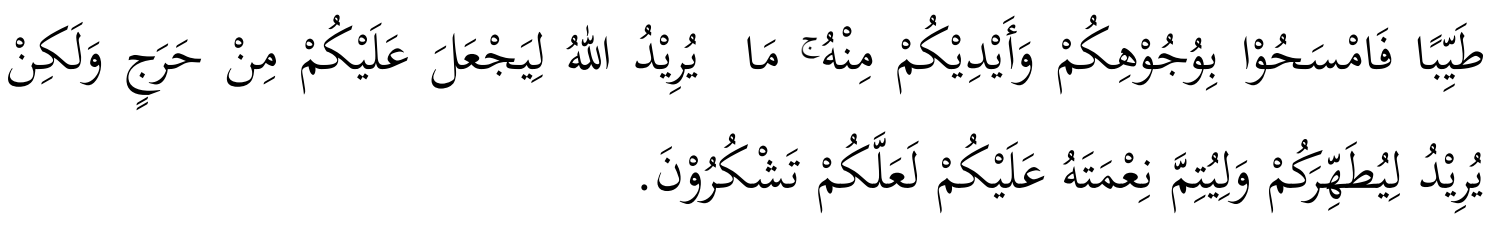

"O Those who believe, when you want to do prayers, then wash your face and your hands up to the elbow, and thou shalt say thy head and (wash) your feet up with both ankles, and if ye shall be unclean, and if you are sick or on the way or back from the place of the waste or touching the woman, then ye have not obtained water, then do tayammum with the good ground (clean), And your hands shall be with the land. God does not make it difficult for you, but he is about to cleanse you and perfect his favor for you, that you may be grateful. "QS. Al-Maidah: 6)

In this verse, the parts that are washed during Ablution are the face, hands to the elbow, head, and foot to the ankles. These passages are washed in sequence according to the sound in the verse and preceded by intention as part of the obligatory Ablution.

To carry out Ablution, some conditions must be met before doing Ablution. These requirements are Islam, Tamyeez (can distinguish good things), small or not in the state of the great impurity, using the holy water and purify, unhindered water to the limbs prescribed in Ablution, and knowing which parts include the obligatory or Sunnah in Ablution.

In the ablution, there is also something to do when doing an ablution or commonly called a fardlu or Rukun ablution. There is 6 ablution from the intention, to wash the face, to wash both hands to the elbow, wipe the head, wash the soles of the feet until the ankles, and the last is orderly. While the Sunnah in Ablution is reading the base, wash both hands until the wrist, Gargle, rinsing water to the nose) and Istintsar (remove water from the nose), wipe the entire head, wipe both the outer and inner ears, tayammum (put the right part of the ablution), purify members of ablution three times, and Muwalah (not interrupt with other work).

\section{METHOD}

In this study, the method used is a qualitative descriptive method, which is the problem-solving research using empirical data to understand social phenomena through a holistic picture and expand the sense of meaning. In research, the data source is a very important factor, because the data source will affect the quality of the research results. Data source consists of primary data source and secondary data source.(Bevan, 2014; Giorgi, 1997; Sandelowski, 2000; Vaismoradi et al., 2016)

Two data sources are human and not human. The human data source serves as a key informant. While non-human data sources are relevant documents with the focus of research. The data in this study, in the form of everything in the form of 
narrative data, was obtained through several research procedures. This research data, obtained from data sources through; (a) In-depth interview with this interview the researcher did with the chairman of Madrasah Diniyah Baitul Muttaqin and Madrasah Diniyah At-Taqwa Gareman. Ustadz/Ustadzah, the Regent and students; (b) Observation, with participatory observation is conducted to observe the education process Thoharoh in early childhood; (c) The documentation is used to support data collection efforts such as photographs and recording activities or interviews.

The data analysis techniques used in this study are data analysis techniques referring to the interactive models of Miles and Huberman. Analysis of data in research conducted since plunging into the field, observation during the implementation of research in the field and after completion of research in the field. Data analysis is done by collecting data obtained into a category, describing data into units, analyzing important data, then compiling or presenting data. Data tested for validity by using participation extension, observation persistence, and triangulation

\section{RESULTS AND DISCUSSION}

Babadan Village is one of the kelurahan or villages in the district Patianrowo Nganjuk District, East Java province. Babadan has 4 Madrasah Diniyah and 7 educational parks of the Qur'an. Madrasah Diniyah (Madin) Baitul Muttaqin is located under Yayasan Baitul Muttaqin Wassholihin. The chief is H.M Mubin with statistical number Madrash Diniyah (NSMD) 311235180398.

In addition to Madrasah Diniyah Baitul Muttaqin This study also involved Madin At-Taqwa Hamlet Gareman Desa Babadan Patianrowo. Madin was headed by Faridatul Husna. The second Madin is Madin in Babadan village.

The education of Thoharoh in Madrasah Diniyah Baitul Muttaqin is held very interestingly and exciting. Adjusting to the character of a unique early childhood and only able to focus on something in a short duration than the conforming is made variously so it is not boring children. Given this period of the Golden Age, then we need to plant the basic things that will be imprinted on their self-life.

The education of Thoharoh begins with the introduction of a mild question and answer leads to the topic Thoharoh, such as "who has prayers?", "What must be done before prayer?". Children also answered enthusiastically. The first "Ablution" taught was to embed their love for holier. So they had a desire to always be in the holy State and they would do that with sincerity and pleasure without resorted.

To instill their love of Thoharoh (chaste) will be a friend who always keeps Ablution. This friend was named Bilal ibn Rabah. Sang Ustadz asked "Should the children of any time ablution depart for the Madrasah?" simultaneously the children answered "no". Ustadznya asked again, "When are children ablution?". The children replied, "If you want prayers sometimes Ablution sometimes not". 
Ustadz asked again, "Want to hear the story of the Prophet's companions who always keep ablution?". Children also spontaneously answered "Mau". Ustadz then told about the prophet's friend Bilal bin Rabah. The story is conveyed by dramatization. There is someone who serves as Bilal accompanying the story of the Ustadz.

Start Ustadz telling about Bilal ibn Rabah:

"In the days of Rasulullah lived a friend named Bilal ibn Rabah al-Babasyi. She is tall, thin, and her hair is dense and is melodious. Bilal was a slave of Umayah ibn Khalaf. Knowing Bilal entered Islam, Umayah immediately tortured Bilal. Hearing the news, Abu Bakar Ash-Shidiq and then liberated Bilal from his master. Bilal is also known as Muezzin or the one who has Adzan.

One day after prayer shubuh in the congregation, the Prophet called Bilal and asked him: "Tell me the greatest of your reward that you have been working on? For I (the Prophet) heard the voice of your footsteps in heaven at the time of the Isro ' mi'roj. ' Bilal replied: o Messenger of Allah I never worked out the practice in my opinion, but I always keep the Ablution in the day or night and I pray ablution ".

Subhanallah children, Bilal is still in the world, his footsteps have been heard in heaven. Who wants to go to heaven like Bilal? "The children also spontaneously answered" me. " Ustadz asked again: "If you want to go to heaven like Bilal means to like what?". "The love of Wudoo" answered the innocent child.

Developing this behavior is important because when children are motivated to do Ablution, then he gladly is taught sacred ordinances. By telling the Islamic figure Bilal bin Rabah It is also expected that the child increasingly loves and makes an example for them to emulate.

One of the things to start introducing ablution to children is introduced by hand Pat. The following is the hand of ablution introduced:

\section{\#\#Baca bismillah sambal cuci tangan\#\# \\ \#\# kumur kumur cuci hidung basuh muka \#\# \\ \#\# tangan sampai ke siku kepala dan telinga\#\# \\ \#\#terakir cuci kaki lalu doa\#\#}

After being introduced by Pat Ablution, then the children began to be introduced to begin the procedure of ablution with the game. The child can, come forward and then hold the poster (the big inscription) one sequence of ablution and all the children who carry the writing forward in the front. Starting from Order 1) intention, 2) wash your fingers and palms, 3) gargle, 4) cleanse the nasal cavity, 5) wash the face, 6) wash both hands until the elbow, 7) Wipe the head, 8) wipe the outside and in the ear, 9) wash the foot until both ankles, 10) orderly/sequential. After all the posters of the Ablution sequence were shown, then closed again and the child was invited to play a guess. When the children answer, then the poster order of ablution will be opened one by one starting from the first order until the last sequence.

To introduce a pillar of ablution, the child who carries the poster of the Ablution was invited forward 1 step, namely the child carrying the poster number 1, 5, 6, 7 
9, 10. Then Ustadz explains that the poster brought by his friend in front of it is a pillar of Ablution. Rukun ablution is all activities that must be done when we do Ablution if we do not do then our ablutions become invalid. Surely when our ablution is not valid, if we pray then our prayers are also not valid. Rukun ablution is closed again and the children guess and say the pillars of ablution starting from number 1 to number 6, namely 1) intention, 2) wash the face, 3) Cook both hands until the elbow 4) wipe the head, 5) wash the foot until both the ankles and the 6th) order or sequence is not allowed when we do Ablution, we wash the feet first new face.

The introduction of Sunnah's ablution is done in the same way. When there is Ablution, then the one who carries a poster of the ablution pillars forward to the next step. Now alternately, that brings the poster Sunnah ablution number 2, 3, 4, and 8 forward to the front one step. Then a poster of Sunnah ablution is read together from the washing of fingers and palms, Gargle, cleaning the nasal cavity, rubbing the inside and outside the ears. Plus, it takes the right part of the left. For example, wash hands. Because our hands are two, then the first thing we have to flush is the right hand. Only then, wash the left hand. Each ablution movement was circumcised three times. And do not after Ablution to pray so that his ablutions become perfect.

Knowledge of ablution already children get. It's time to demonstrate or practice. All ablution movements were given examples and children were asked to follow the movement. The children stood up and followed the movements modeled. Start from the right way to wash your fingers right and left, the right and left palms by clearing the fingers with water, gargle until there is no food left in the mouth, cleaning the right and left nostrils until clean so that no dirt is annoying, wash the face, the upper part of the limit from the growth of the hair, as well as the right side and left, the bottom of the face borders until the lower chin. After that, proceed to wash the right hand until the elbow and wash the left hand until the elbow, followed by rubbing part of the head. Then cleanse the inner right ear by inserting the index finger and cleaning it, the outer ear by rotating the thumb finger, as well as the left ear. Then wash the right foot until the ankles and wash the left foot until the ankles. All the ablution movements were performed three times and ended with prayer.

After each child practices ablutions in their respective place, the children are allowed to move forward to practice the movement of ablution. Ustadz can choose 2 girls and one boy to advance. When children are in practice, Ustadz can correct while providing the correct example of how to practice the right ablution movement

This method of demonstration is deliberately used so that children are easier to remember. With three actions that are showing, doing and telling. By showing (example), practicing and telling or explaining new experiences, the child will be 
easy to form and become a basic provision for them to apply it to everyday life in the real world, so that when the Thoharoh is true, then it is hoped that other worship will be legitimate.

Also, for children to understand the benefits of ablution, make entertainment educational magic and assisted by an educational clown. If usually, the clown is only on the birthday event to entertain, in this Thoharoh learning deliberately presented to the child's memory about Thoharoh increasingly masturbation and become unforgettable memories. Given the importance of Thoharoh which is the basis of all worship activities.

In this educative Magic Entertainment, the clown helps to provide three glasses of watercolored orange. One of them is given a solution of tea to water which is later distributed in children whose practice is the most correct Ablution. While the other 2 children who still have shortcomings in the Ablution given the usual solution. This solution will remain orange even though we dip the water repeatedly. Different from the solution that is given tea to water, when dyed fabric with times then this orange solution will turn white.

This magic contains philosophical values that want to be implanted in the child that the more frequent ablutions and your ablution is right then the water will be clearer. Clear not only outside but also inside. It means that with this ablution will grow healthy both soul and body. With this magic, children are expected to be motivated to always do Ablution properly. Kids look very entertained and enjoy an educational magic game that they have never seen.

The second magic is with the media magic bag. In this magic, the children are asked: "if the Ablutionnya is sincere and perfect, what can we do?" The answer is not immediately said by word but made in one interesting game. So that children can capture Diasampaikan messages easily. Two children are asked to come forward. They were asked to put his hand on the magic bag. The first child inserts a hand into the magic bag, and the child is buried to find the magic bag in a blank state. After that, the second child is asked to put his hand on the magic bag and the child finds the magic bag in an empty state as well. The clown asked the first child to put his hand on the magic bag again, apparently, the bag was still empty. Furthermore, the second child is asked to put his hand on the magic bag, this time the child finds a magical bag containing the inscription "PAHALA".

\section{CONCLUSION}

Learning Thoharoh in early childhood uses an interesting and fun way. First, the children were implanted to have the desire to be chaste by the story of Bilal. Then taught pillars, sunnah and conditions of ablution with the game. All Gerakin ablution and Tayammum were demonstrated and taught the benefits of Ablution with magic games. To motivate and see the feedback from the understanding of children is held Thoharoh festival. 


\section{REFERENCES}

Ahmad, M. S. (2014). Thaharah: Makna Zawahir dan Bawahin dalam Bersuci. Jurnal Ilmu Syariah.

Anderson, L. M., Shinn, C., Fullilove, M. T., Scrimshaw, S. C., Fielding, J. E., Normand, J., \& Carande-Kulis, V. G. (2003). The effectiveness of early childhood development programs: A systematic review. In American Journal of Preventive Medicine. https://doi.org/10.1016/S0749-3797(02)00655-4

Ashiabi, G. S. (2007). Play in the preschool classroom: Its socioemotional significance and the teacher's role in play. Early Childhood Education Journal. https://doi.org/10.1007/s10643-007-0165-8

Australian Institute for Teaching and School Leadership, Teaching, A., \& Leadership, S. (2011). National Professional Standards for Teachers. Education Services Australia. https://doi.org/10.1177/002248715901000125

Bevan, M. T. (2014). A method of phenomenological interviewing. Qualitative Health Research. https://doi.org/10.1177/1049732313519710

Bjorklund, D. F., \& Pellegrini, A. D. (2000). Child development and evolutionary psychology. Child Development. https://doi.org/10.1111/1467-8624.00258

CARTA, J. J. (1994). Developmentally Appropriate Practices. Journal of Early Intervention. https://doi.org/10.1177/105381519401800402

Crittenden, P. M. (2005). Attachment Theory, Psychopathology, and Psychotherapy: The Dynamic-Maturational Approach. Psicoterapia. https://doi.org/10.1007/s13398-014-0173-7.2

Crittenden, P. M. K., \& Dallos, R. (2009). All in the family: Integrating attachment and family systems theories. Clinical Child Psychology and Psychiatry. https://doi.org/10.1177/1359104509104048

Dyson, M., Plunkett, M., \& McCluskey, K. (2018). Australian Professional Standards for Teachers. In Success in Professional Experience. https://doi.org/10.1017/9781108550703.014

Encyclopedia of bilingualism and bilingual education. (1998). Choice Reviews Online. https://doi.org/10.5860/choice.36-1907

Giorgi, A. (1997). The theory, practice, and evaluation of the phenomenological method as a qualitative research procedure. Journal of Phenomenological Psychology. https://doi.org/10.1163/156916297X00103

Harmon, E. B. (1967). The Maturational Processes and the Facilitating Environment. Journal of the American Academy of Child Psychiatry. https://doi.org/10.1016/s0002-7138(09)61671-x

Hobson, S. (2014). Religion and spirituality. In The Cambridge Companion to Modernist Culture. https://doi.org/10.1017/CC09781107278882.004

Ketut Sudarsana, O. I. (2017). Membentuk Karakter Anak Sebagai Generasi Penerus Bangsa Melalui Pendidikan Anak Usia Dini. Membentuk Karakter Anak.

Khobir, A. (2013). Pengaruh pendidikan thaharah terhadap sikap hidup sehat santri pondok pesantren di Pekalongan. Jurnal Penelitian.

Lillard, A. S. (2012). Preschool children's development in classic Montessori, supplemented Montessori, and conventional programs. Journal of School Psychology. https://doi.org/10.1016/j.jsp.2012.01.001 
Lillard, A. S. (2013). Playful learning and Montessori education. American Journal of Play.

MONTESSORI. (1952). In The Lancet. https://doi.org/10.1016/S01406736(52)90657-0

Needham, A., \& Libertus, K. (2008). Neonativism. In Encyclopedia of Infant and Early Childhood Development. https://doi.org/10.1016/B978-0123708779.00108-0

Newcombe, N. S. (2011). What is neoconstructivism? Child Development Perspectives. https://doi.org/10.1111/j.1750-8606.2011.00180.x

Newcombe, N. S. (2013). Cognitive development: Changing views of cognitive change. In Wiley Interdisciplinary Reviews: Cognitive Science. https://doi.org/10.1002/wcs.1245

Ramscar, M., \& Gitcho, N. (2007). Developmental change and the nature of learning in childhood. Trends in Cognitive Sciences. https://doi.org/10.1016/j.tics.2007.05.007

Salsberry, P. J., \& Reagan, P. B. (2005). Dynamics of early childhood overweight. Pediatrics. https://doi.org/10.1542/peds.2004-2583

Sandelowski, M. (2000). Whatever happened to qualitative description? Research in Nursing \& Health. https://doi.org/10.1002/1098240x(200008)23:4<334::aid-nur9>3.0.co;2-g

Schachter, R. E., Spear, C. F., Piasta, S. B., Justice, L. M., \& Logan, J. A. R. (2016). Early childhood educators' knowledge, beliefs, education, experiences, and children's language- and literacy-learning opportunities: What is the connection? Early Childhood Research Quarterly. https://doi.org/10.1016/j.ecresq.2016.01.008

Schorn, R. (1952). MARIA MONTESSORI. Bildung Und Erziehung. https://doi.org/10.7788/bue-1952-jg42

Shampo, M. A., \& Kyle, R. A. (1976). Maria Montessori (1870-1952). Journal of the American Medical Association. https://doi.org/10.1001/jama.235.8.815

Soebahar, A. H. (2013). Kebijakan Pendidikan Islam: Dari Ordonansi Guru Sampai UU Sisdiknas. Rajawali Press.

Stendler, C. (1965). The Montessori Method. Educational Forum. https://doi.org/10.1080/00131726509339429

Stipek, D., \& Byler, P. (2004). The early childhood classroom observation measure. Early Childhood Research Quarterly. https://doi.org/10.1016/j.ecresq.2004.07.007

Sujiono, Y. N. (2009). Konsep dasar pendidikan anak usia dini.

Tremblay, R. E., Nagin, D. S., Séguin, J. R., Zoccolillo, M., Zelazo, P. D., Boivin, M., Pérusse, D., \& Japel, C. (2004). Physical aggression during early childhood: trajectories and predictors. Pediatrics. https://doi.org/10.1542/peds.114.1.e43

Vaismoradi, M., Jones, J., Turunen, H., \& Snelgrove, S. (2016). Theme development in qualitative content analysis and thematic analysis. Journal of Nursing Education and Practice. https://doi.org/10.5430/jnep.v6n5p100

Vygotsky, L., \& Vygotsky, L. S. (2006). The Development of Scientific Concepts in Childhood. In Thought and language. https://doi.org/10.1037/11193-006

Winnicott, D. W. (2018). The maturational processes and the facilitating 
environment: Studies in the theory of emotional development. In The Maturational Processes and the Facilitating Environment: Studies in the Theory of Emotional Development. https://doi.org/10.4324/9780429482410

Wiyani, N. A. (2014). Psikologi perkembangan anak usia dini. Yogyakarta: Gava Media.

Zelazo, P. D., Müller, U., Frye, D., Marcovitch, S., Argitis, G., Boseovski, J., Chiang, J. K., Hongwanishkul, D., Schuster, B. V, \& Sutherland, A. (2003). The development of executive function in early childhood. Monographs of the Society for Research in Child Development.

Zhang, K. C. (2014). Through a Spiritual Lens: Early Childhood Inclusive Education in Hong Kong. Journal of Religion and Health. https://doi.org/10.1007/s10943-013-9771-5 